\title{
Signal transduction via TRPM3 channels in pancreatic $\beta$-cells
}

\author{
Gerald Thiel, Isabelle Müller and Oliver G Rössler \\ Department of Medical Biochemistry and Molecular Biology, University of Saarland Medical Center, Building 44, \\ D-66421 Homburg, Germany
}

Correspondence should be addressed to G Thiel

Email

gerald.thiel@uks.eu

\begin{abstract}
Transient receptor potential melastatin 3 (TRPM3) channels are non-selective cation channels that are expressed in insulinoma cells and pancreatic $\beta$-cells. Stimulation of TRPM3 with the neurosteroid pregnenolone sulfate induces an intracellular signaling cascade, involving a rise in intracellular $\mathrm{Ca}^{2+}$ concentration, activation of the protein kinases Raf and ERK, and a change in the gene expression pattern of the cells. In particular, biosynthesis of insulin is altered following activation of TRPM3 by pregnenolone sulfate. Moreover, a direct effect of TRPM3 stimulation on insulin secretion has been reported. The fact that stimulation of TRPM3 induces a signaling cascade that is very similar to the signaling cascade induced by glucose in $\beta$-cells suggests that TRPM3 may influence main functions of pancreatic $\beta$-cells. The view that TRPM3 represents an ionotropic steroid receptor of pancreatic $\beta$-cells linking insulin release with steroid hormone signaling is discussed.
\end{abstract}

\section{Introduction}

Transient receptor potential (TRP) channels are a heterogeneous superfamily of cation influx channels, separated in the subfamilies TRPC (canonical), TRPV (vanilloid), TRPM (melastatin), TRPML (mucolipins), TRPP (polycystin), and TRPA (ankyrin). Many biological functions have been connected with TRP channel activation, including regulation of $\mathrm{Ca}^{2+}$ homeostasis, tumorigenesis, sensory temperature, and pain sensation.

In pancreatic $\beta$-cells, several members of the TRP family of cation channel proteins are expressed (Colsoul et al. 2011, Islam 2011). The channels with the highest expression are TRPML1 and TRPP2. Functional roles have been attributed to TRPA1, TRPM2, and TRPM5. Activation of TRPA1 channels by the agonist allyl isothiocyanate stimulates insulin release from insulinoma cells and primary isolated pancreatic $\beta$-cells (Cao et al. 2012). Secretion was inhibited following incubation of the cells with a TRPA1-specific antagonist, confirming the connection between TRPA1 channel activation and insulin secretion. TRPM2 is activated by $\mathrm{H}_{2} \mathrm{O}_{2}$ and reactive oxygen species. Accordingly, TRPM2 function has been correlated with $\beta$-cell apoptosis (Hara et al. 2002). TRPM2-deficient mice have higher basal glucose levels and an impaired glucose tolerance (Uchida et al. 2011). TRPM5 channels are important constituents of $\mathrm{Ca}^{2+}$-activated cation current in $\beta$-cells. Correspondingly, reduced channel activity could be measured in $\beta$-cells of TRPM5-deficient mice (Colsoul et al. 2010). Moreover, TRPM5 is involved in glucose-induced insulin release as demonstrated by impaired glucose tolerance performed with TRPM5deficient mice, due to reduced plasma insulin levels (Brixel et al. 2010, Colsoul et al. 2010).

\section{TRPM3 channels}

TRPM3 has the typical features of TRP channels, including six transmembrane domains and a pore domain between the fifth and sixth transmembrane domain. Both amino

Published by Bioscientifica Ltd 
and carboxy termini are located in the cytosol. TRPM3 contains the TRP domain, a highly conserved motif, located on the C-terminal side of the sixth transmembrane domain. In addition, calmodulin-binding sites have been detected within the N-terminal cytosolic domain of TRPM3 (Halokovska et al. 2012). The modular structure of TRPM3 is depicted in Fig. 1A.

The TRPM3 gene encodes many TRPM3 channel isoforms due to alternative splicing (Lee et al. 2003,

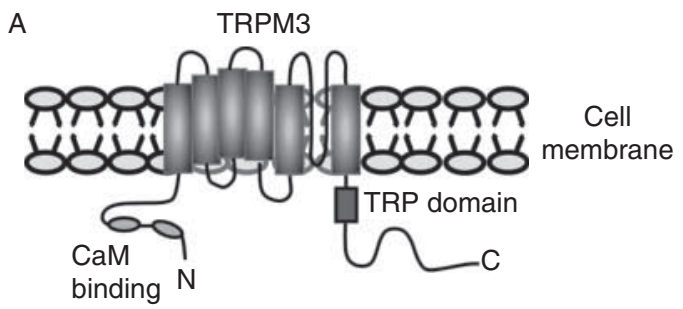

B

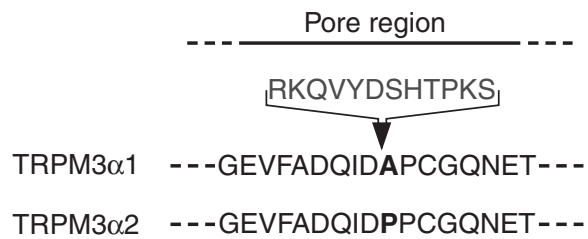

C Islets
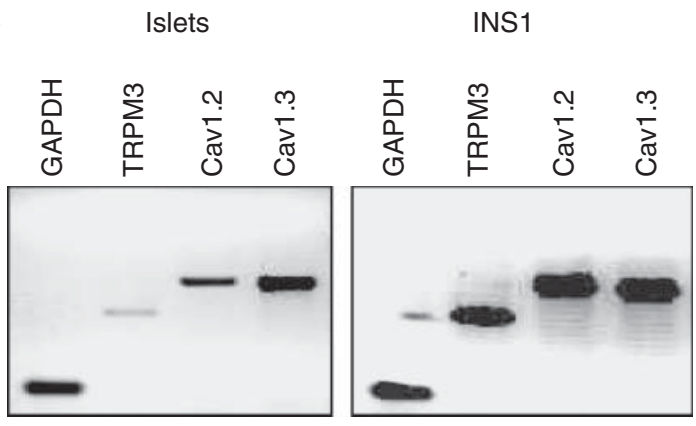

Figure 1

Modular structure, membrane topology, and expression of TRPM3. (A) Schematic representation of the modular structure of TRPM3 channels. TRPM3 has six transmembrane domains with a pore-forming domain between transmembrane regions 5 and 6 . Both the $\mathrm{N}$ - and $\mathrm{C}$-termini are located in the cytosol. The $\mathrm{N}$-terminus contains two calmodulin-binding sites encompassing amino acids 35-124 and 291-382. The C-terminus contains the TRP domain on the C-terminal side of the sixth transmembrane domain. (B) Primary sequence of the putative pore region of the TRPM3 splice variants TRPM3 $\alpha 1$ and TRPM3 $\alpha 2$ (Oberwinkler et al. 2005). (C) Expression of TRPM3 and voltage-gated $\mathrm{Ca}^{2+}$ channels Cav1.2 and Cav1.3 in islets and insulinoma cells. RNA was prepared from islets and INS1 insulinoma cells. Expression of TRPM3 was monitored via RT-PCR using gene-specific primers. As a control, expression of GAPDH was assessed (reproduced from Müller I, Rössler OG \& Thiel G 2011 Pregnenolone sulfate activates basic region leucine zipper transcription factors in insulinoma cells: role of voltage-gated $\mathrm{Ca}^{2+}$ channels and transient receptor potential melastatin 3 channels. Molecular Pharmacology 80 1179-1189 with kind permission from the American Society for Pharmacology and Experimental Therapeutics).
Grimm et al. 2005, Oberwinkler et al. 2005). In fact, TRPM3 encompasses the largest number of splice variants within the TRP family of channel proteins. Of particular interest are the TRPM3 isoforms, TRPM $3 \alpha 1$ and TRPM $3 \alpha 2$, that differ within the pore region of the channel between the fifth and sixth transmembrane region (Fig. 1B). Within this pore region, TRPM $3 \alpha 1$ has 12 additional amino acids in comparison to TRPM $3 \alpha 2$. In addition, TRPM $3 \alpha 1$ has an alanine residue at the C-terminal of the insertion, while TRPM $3 \alpha 2$ has a proline residue at this position. Physiological experiments revealed that TRPM $3 \alpha 1$ channels are poorly permeable for divalent cations, while TRPM $3 \alpha 2$ channels are at least 10 times more permeable for $\mathrm{Ca}^{2+}$ and at least 100 times more permeable for $\mathrm{Mg}^{2+}$ (Oberwinkler et al. 2005). Thus, alternative splicing produces TRPM3 channels of entirely different cation permeability, by changing the primary sequence of the pore region of the channel. In addition, a TRPM3 splice variant termed TRPM $3 \alpha 7$ that lacks amino acid residues 512-529 displays no ionic current (Frühwald et al. 2012), suggesting that this variant functions as a decoy receptor. In INS1 insulinoma cells, this variant makes up $7.2 \%$ of the TRPM3 transcripts. TRPM $3 \alpha 7$ forms heteromeric complexes with TRPM $3 \alpha 2$, leading to a reduced $\mathrm{Ca}^{2+}$ influx following stimulation (Frühwald et al. 2012).

TRPM3 channels are prominently expressed in various tissues, including kidney, liver, ovary, brain, spinal cord, pituitary, vascular smooth muscle, and testis (Grimm et al. 2003, Lee et al. 2003, Naylor et al. 2010). Interestingly, TRPM3 is expressed in insulinoma cells and $\beta$-cells of the pancreas, as shown in Fig. 1C.

\section{Ligands and inhibitors of TRPM3 channels}

TRPM3 channels exhibit constitutive activity following overexpression in HEK293 cells (Grimm et al. 2003, 2005, Oberwinkler et al. 2005). Low-level constitutive TRPM3 activity has also been detected in vascular smooth muscle cells (Naylor et al. 2010).

TRPM3 is activated by $\beta$-cyclodextrin, while the role of D-erythro-sphingosine as a TRPM3 ligand is a matter of debate and may depend on the experimental design (Grimm et al. 2005, Wagner et al. 2008, Naylor et al. 2010). Surprisingly, TRPM 3 channels are activated by the dihydropyridine nifedipine, an inhibitor of voltage-gated $\mathrm{Ca}^{2+}$ channels, while the structurally related compounds nimodipine, nicardipine, and nitrendipine were inactive (Wagner et al. 2008). Cholesterol, the precursor metabolite of pregnenolone, progesterone, and mefenamic acid prevents TRMP3 channel activation (Naylor et al. 2010,

Published by Bioscientifica Ltd 
Klose et al. 2011, Majeed et al. 2012). The antidiabetic $\operatorname{PPAR} \gamma$-agonists rosiglitazone and troglitazone function as TRPM3 channel blockers (Majeed et al. 2011). Recently, the screening of a compound library revealed that citrus fruit flavanones such as naringenin and hesperetin and fabacea secondary metabolites selectively inhibit TRPM3 channel activation (Straub et al. 2013).

The neurosteroid pregnenolone sulfate, the sulfated form of pregnenolone, has been found to activate TRPM3 channels in insulinoma cells and pancreatic $\beta$-cells (Wagner et al. 2008, Klose et al. 2011, Mayer et al. 2011, Müller et al. 2011) as well as in other cell types. Stimulation with pregnenolone sulfate also activates TRPM3 channels in HEK293 cells, vascular smooth muscle cells, and synovial fibroblasts (Ciurtin et al. 2010, Majeed et al. 2010, Naylor et al. 2010, Klose et al. 2011), confirming that TRPM3 functions as a $\mathrm{Ca}^{2+}$-permeable non-selective cation channel. Furthermore, studies involving TRPM3-deficient mice revealed that TRPM3 is the major receptor for pregnenolone sulfate in dorsal root and trigeminal ganglia (Vriens et al. 2011). The fact that pregnenolone sulfate stimulates TRPM3 channel activity is the basis for the hypothesis that TRPM3 functions as an ionotropic steroid receptor of pancreatic $\beta$-cells linking insulin release with steroid hormone signaling (Frühwald et al. 2012).

\section{Pregnenolone sulfate: a ligand for different channels and receptors}

Pregnenolone sulfate is not a TRPM3-specific ligand, as this steroid also exerts modulatory effects on several types of receptors and ion channels including the $\mathrm{N}$-methylD-aspartate (NMDA) receptor, the gamma amino butyric acid-A receptor, voltage-gated $\mathrm{Ca}^{2+}$ channels, and Kir2.3 $\mathrm{K}^{+}$channels (Horak et al. 2004, Chen \& Sokabe 2005, Hige et al. 2006, Kobayashi et al. 2009, Chen et al. 2010, Kostakis et al. 2011, Mayer et al. 2011, Wang 2011). The analysis of chimeric NMDA receptors composed of NR2B and NR2D domains demonstrated that a 'steroid modulatory domain' (SMD1) on the NMDA receptor subunit NR2B is crucial for the stimulation of NR2B-containing NMDA receptors by pregnenolone sulfate. This domain encompasses the extracellular located $\mathrm{J} / \mathrm{K}$ helices of the receptor as well as the contiguous fourth transmembrane domain (Jang et al. 2004). The identification of SMD1 provides a structural component for the pregnenolone sulfate-induced activation of NR2B-containing NMDA receptors.

The site attributed to pregnenolone sulfate binding to TRPM3 channels has yet to be identified. Overlay experiments revealed that pregnenolone sulfate, progesterone, and dihydrotestosterone bound to TRPM3 in vitro (Majeed et al. 2012). Given the fact that other members of the TRPM subfamily (TRPM2, TRPM7, TRPM8) are not activated by pregnenolone sulfate (Wagner et al. 2008), the strategy to generate and analyze chimeric TRP channels composed of TRPM3 and one of the other pregnenolone sulfate-insensitive TRPM channels may lead to the identification of a 'SMD1' within the TRPM3 molecule. The chemical requirements for steroids to activate TRPM3 channels have been investigated using HEK293 cells expressing TRPM3 channels. The results revealed the importance of a sulfate group at ring $\mathrm{A}$ and a cis ( $\beta$ ) configuration of the side group of pregnenolone sulfate (Majeed et al. 2010). Steroids including progesterone, $17 \beta$-estradiol, $17 \beta$-estradiol sulfate, dihydrotestosterone, aldosterone, cortisol, and vitamins $\mathrm{D}_{2}$ and $\mathrm{D}_{3}$ were ineffective in the stimulation of $\mathrm{Ca}^{2+}$-influx via the TRPM3 channel (Majeed et al. 2010). These results argue for the existence of a specific and unique steroid binding site on the TRPM3 molecule.

\section{Regulation of intracellular $\mathrm{Ca}^{2+}$ concentration in pancreatic $\beta$-cells by TRPM 3 and voltage-gated $\mathrm{Ca}^{2+}$ channels}

In pancreatic $\beta$-cells, the closure of $\mathrm{K}_{\mathrm{ATP}}$-regulated potassium channels following glucose uptake and metabolism induces the depolarization of the plasma membrane due to the activation of L-type voltage-gated $\mathrm{Ca}^{2+}$ channels. $\mathrm{Ca}^{2+}$ influx via these voltage-dependent $\mathrm{Ca}^{2+}$ channels is necessary for glucose-induced insulin secretion. Accordingly, pharmacological inhibition of voltage-gated $\mathrm{Ca}^{2+}$ channels blocks glucose-induced insulin secretion as well as glucose-induced transcription (Trus et al. 2007, Mayer \& Thiel 2009, Yang et al. 2010). Likewise, pharmacological activation of voltage-gated $\mathrm{Ca}^{2+}$ channels increases insulin secretion in the absence of glucose (Yang et al. 2010). Insulin-secreting INS1 insulinoma cells and pancreatic $\beta$-cells are responsive to pregnenolone sulfate stimulation, leading to a rapid influx of $\mathrm{Ca}^{2+}$ ions into the cells (Wagner et al. 2008, Islam 2011; Fig. 2). This effect is based on the expression of $\mathrm{Ca}^{2+}$-permeable splice variants such as TRPM $3 \alpha 2$ in pancreatic $\beta$-cells. Intracellular signaling induced by both activation of L-type $\mathrm{Ca}^{2+}$ channels or TRPM3 channels is impaired by chelating extracellular or intracellular $\left[\mathrm{Ca}^{2+}\right]$ (Mayer et al. 2011). Experiments involving expression of a TRPM3-specific short hairpin RNA revealed that TRPM3 is required to induce the $\mathrm{Ca}^{2+}$-dependent

Published by Bioscientifica Ltd. 


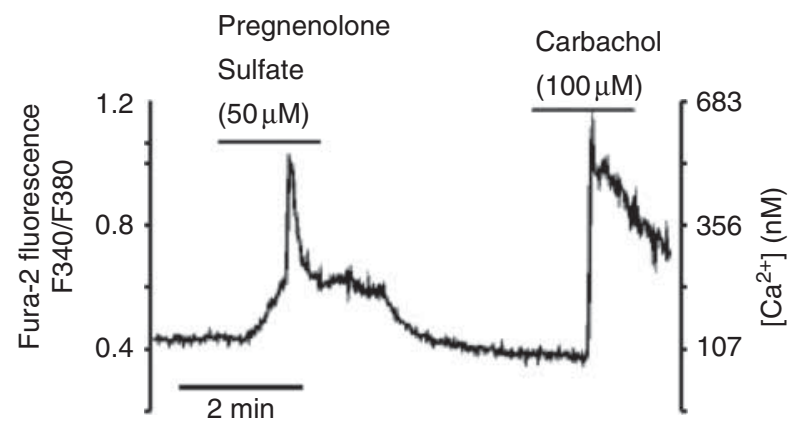

Figure 2

$\mathrm{Ca}^{2+}$ influx into human pancreatic $\beta$-cells following stimulation with pregnenolone sulfate $(50 \mu \mathrm{M})$. As a control, cells were stimulated with carbachol $(100 \mu \mathrm{M}) .\left[\mathrm{Ca}^{2+}\right]_{i}$ was measured from fura-2-loaded $\beta$-cells (reproduced with modifications from Islam MS 2011 TRP channels of islets. In: Transient receptor potential channels. Advances in Experimental Medicine and Biology 704 811-830 (Fig. 42.1) with kind permission from Springer Science + Business Media B.V.).

intracellular signaling cascade in pregnenolone sulfatestimulated insulinoma cells that are maintained in the medium containing low glucose concentrations ( $2 \mathrm{mM})$. However, the initial $\mathrm{Ca}^{2+}$ influx into the cells, mediated by TRPM3 activation, is not sufficient to induce an intracellular signaling cascade, leading to changes in gene transcription. Rather, activation of voltage-gated $\mathrm{Ca}^{2+}$ channels is additionally required, as incubation of the cells with verapamil, a voltage-gated $\mathrm{Ca}^{2+}$ channel blocker, inhibits the signaling cascade induced by pregnenolone sulfate under these conditions (Mayer et al. 2011; Fig. 3). Thus, we propose that stimulation of TRPM3 with pregnenolone sulfate induces a depolarization of the plasma membrane, leading to the activation of L-type voltage-gated $\mathrm{Ca}^{2+}$ channels, a further influx of $\mathrm{Ca}^{2+}$ into the cells, and the initiation of a signaling cascade that triggers changes in the gene expression pattern of the cells.

Using either intracellular $\mathrm{Ca}^{2+}$ measurement with $\mathrm{Ca}^{2+}$ indicators and/or whole-cell patch-clamp to measure cationic membrane current, TRPM3 stimulation by pregnenolone sulfate is independent of L-type voltage-gated $\mathrm{Ca}^{2+}$ channels. This has been proven in heterologous expression studies of TRPM3 in HEK293 cells that are devoid of L-type voltage-gated $\mathrm{Ca}^{2+}$ channels (Wagner et al. 2008, Majeed et al. 2010). Thus, in a heterologous system, TRPM3 functions as a ligandactivated ionotropic receptor in the absence of L-type voltage-gated $\mathrm{Ca}^{2+}$ channels, leading to an influx of $\mathrm{Ca}^{2+}$ into the cells following stimulation with pregnenolone sulfate. It is not yet known whether the influx of $\mathrm{Ca}^{2+}$ through TRPM3 channels is sufficient to induce an intracellular signaling cascade in HEK293 cells that triggers changes of the gene expression program of the cells.

Experiments performed with pituitary corticotrophs that express functional L-type $\mathrm{Ca}^{2+}$ channels, but only trace amounts of TRPM3 revealed that pregnenolone sulfate stimulation does not induce an intracellular signaling cascade (Müller et al. 2011), indicating that L-type $\mathrm{Ca}^{2+}$ channels do not function as pregnenolone sulfate receptors in this cell type. By contrast, stimulation of insulinoma cells, which are maintained in the medium containing $11 \mathrm{mM}$ glucose, with pregnenolone sulfate induces an intracellular signaling cascade that requires L-type voltage-gated $\mathrm{Ca}^{2+}$ channels and is independent of TRPM3 activation (Mayer et al. 2011). It is not clear whether pregnenolone sulfate directly binds to L-type $\mathrm{Ca}^{2+}$ channels.

\section{Protein kinases and protein phosphatases involved in TRPM3 signaling in pancreatic $\beta$-cells}

Elevation of $\left[\mathrm{Ca}^{2+}\right]_{\mathrm{i}}$ triggers an activation of the protein kinases Raf and ERK in pancreatic $\beta$-cells and insulinoma cells (Benes et al. 1998, 1999, Arnette et al. 2003, Mayer \& Thiel 2009, Duan \& Cobb 2010). The connection between an elevated $\mathrm{Ca}^{2+}$ concentration and the activation of the ERK signaling pathway is accomplished by protein kinase C (PKC), most likely PKC $\alpha$ and PKC $\beta I I$ (Benes et al. 1999) and the protein kinase Raf (Kolch et al. 1993, Corbit et al. 2003, Duan \& Cobb 2010). Given the similarities between glucose and pregnenolone sulfateinduced signaling, it is not surprising that Raf and ERK are activated in pregnenolone sulfate-stimulated insulinoma cells (Mayer et al. 2011). Moreover, pregnenolone sulfateinduced signaling is impaired in insulinoma cells expressing MKP1, a nuclear protein phosphatase that dephosphorylates and inactivates ERK in the nucleus. Thus MKP1 is part of a negative feedback loop inducing dephosphorylation and inactivation of nuclear ERK. In addition, elevated $\left[\mathrm{Ca}^{2+}\right]_{\mathrm{i}}$ may activate calcineurin, a $\mathrm{Ca}^{2+}$-regulated protein phosphatase. Calcineurin is composed of two polypeptides, calcineurin $\mathrm{A}$ and $\mathrm{B}$. Expression of a constitutively active calcineurin A mutant, which lacks the calmodulin-binding site and the C-terminal autoinhibitory domain and which does not require $\mathrm{Ca}^{2+}$ ions for activation, impairs pregnenolone sulfate-regulated signaling in the nucleus (Mayer et al. 2011), suggesting that calcineurin may be part of a second negative feedback loop in the pancreatic $\beta$-cells (Fig. 3).

Published by Bioscientifica Ltd. 


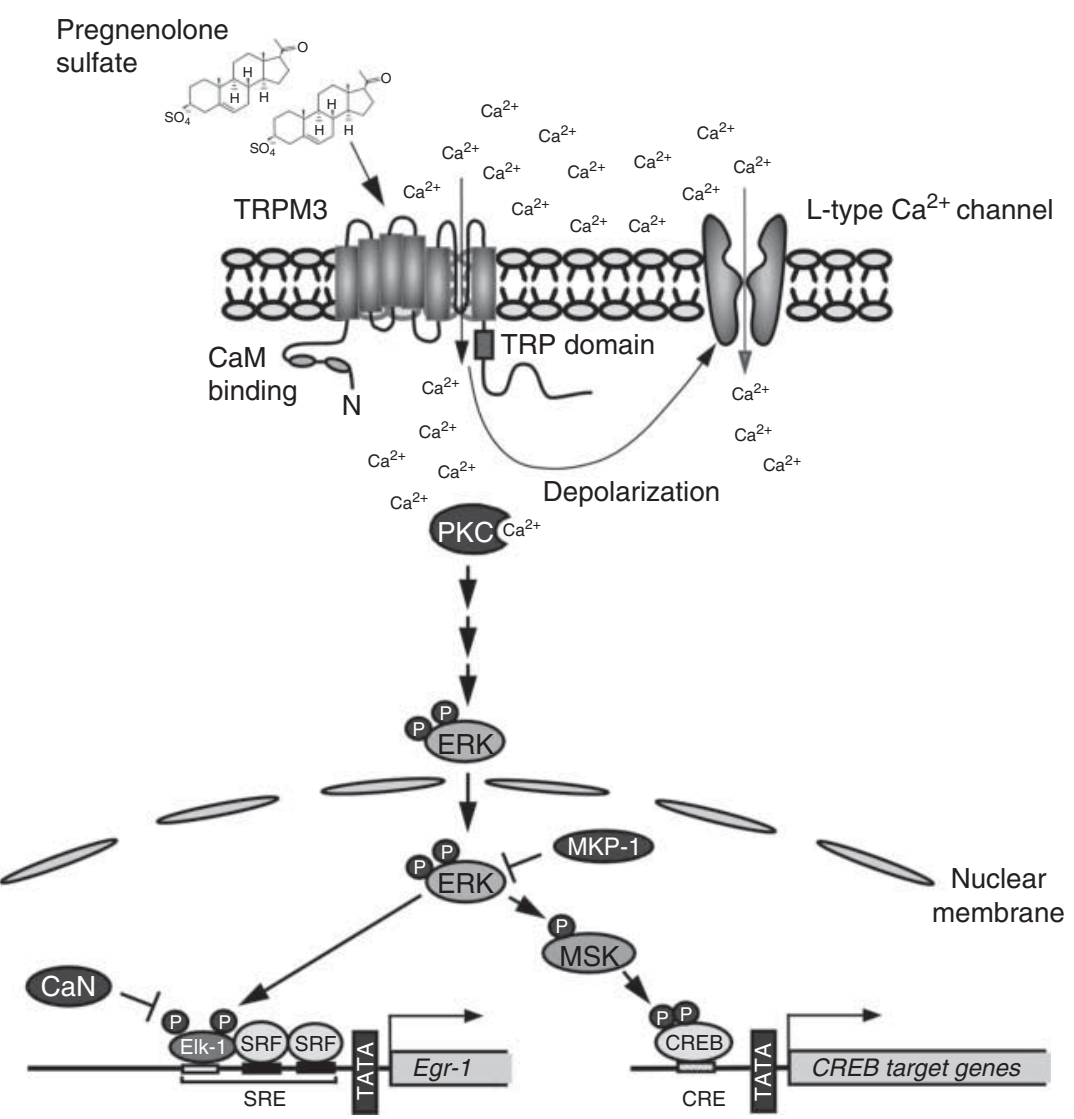

Figure 3

Signal transduction of pregnenolone sulfate in pancreatic $\beta$-cells. Stimulation of insulinoma cells cultured in medium containing $2 \mathrm{mM}$ glucose with pregnenolone sulfate requires both TRPM3 and L-type voltage-gated $\mathrm{Ca}^{2+}$ channels to induce an intracellular signaling cascade. The cytosolic $\mathrm{Ca}^{2+}$ concentration is increased via an influx of $\mathrm{Ca}^{2+}$ ions from outside. Elevation of the intracellular $\mathrm{Ca}^{2+}$ concentration leads to the activation of the ERK signaling cascade, mediated by PKC. A major nuclear substrate for ERK is the ternary complex factor Elk1, an essential component of the

\section{Activation of gene transcription in insulinoma cells and pancreatic $\beta$-cells following activation of TRPM 3 channels}

Elevated levels of glucose have a profound effect on gene transcription in pancreatic $\beta$-cells. Several transcription factors are activated in glucose-stimulated insulinoma or pancreatic $\beta$-cells, including Egr1 (Frödin et al. 1995, Josefsen et al. 1999, Bernal-Mizrachi et al. 2000, Mayer \& Thiel 2009), CREB (Wang et al. 2008, Mayer \& Thiel 2009), Elk1 (Bernal-Mizrachi et al. 2001, Mayer \& Thiel 2009), c-Jun, and c-Fos (Glauser \& Schlegel 2007, Müller et al. $2012 a$ ). Stimulation of insulinoma cells with pregnenolone sulfate activates the biosynthesis of Egr1, a $\mathrm{Ca}^{2+}$. regulated zinc finger transcription factor (Thiel et al. serum response element (SRE) ternary complex. The Egr1 promoter contains five SREs that mediate signal-induced activation of Egr1 gene transcription. Activated ERK phosphorylates in the nucleus the protein kinase MSK that in turn phosphorylates and activates the transcription factor CREB. The phosphatases MKP1 and calcineurin (CaN) function as negative regulators of this signaling cascade by dephosphorylating ERK and Elk1 respectively.

2010), while incubation of the cells with pregnenolone or progesterone has no effect on the Egr1 level within the cells (Mayer et al. 2011).

The activity of the transcription factor activator protein 1 (AP1) is prominently upregulated in glucosestimulated insulinoma cells (Glauser et al. 2006, Müller et al. 2010, 2012a). Pregnenolone sulfate stimulation also leads to a significant elevation of AP1 activity in insulinoma cells (Müller et al. 2011). The AP1 transcription factor was originally described as a heterodimer of the transcription factors c-Jun and c-Fos. These proteins dimerize via their leucine zipper domains, which in turn bring together their basic domains to bind to DNA in a sequence-specific manner. Stimulation with pregnenolone sulfate increases the expression of c-Fos and c-Jun.

Published by Bioscientifica Ltd. 
c-Jun is a substrate for c-Jun N-terminal protein kinases and phosphorylation of c-Jun is required for the activation of the transcriptional activation potential of c-Jun. Accordingly, stimulation of insulinoma cells with pregnenolone sulfate induces the phosphorylation of c-Jun, indicating that it was activated as a result of stimulation (Müller et al. 2011). In addition, phosphorylation of CREB is induced and transcription of a cAMP response element (CRE)-controlled reporter gene is stimulated following pregnenolone sulfate treatment (Fig. 3). In each case, the requirement of TRPM3 has been demonstrated by expressing TRPM3-specific short hairpin RNAs (Mayer et al. 2011, Müller et al. 2011). Hence, pregnenolone sulfate stimulation activates a plethora of transcriptional events in insulinoma cells and pancreatic $\beta$-cells, suggesting that transcriptional changes may be important for the biological functions of TRPM3 stimulation (Fig. 3).

\section{Regulation of insulin biosynthesis and secretion by TRPM3}

The activation of transcription factors in pregnenolone sulfate-stimulated insulinoma cells and pancreatic $\beta$-cells requires the identification of pregnenolone sulfateregulated genes in these cells and the correlation of the biological functions of these gene products with important physiological parameters in the endocrine pancreas. We recently showed that Egr transcription factors play an important role in controlling insulin biosynthesis, glucose homeostasis, and proliferation/cell death of pancreatic $\beta$-cells in vivo (Müller et al. 2012b). Interestingly, the glucose-responsive transcription factor Egr1 induces insulin gene transcription in vitro via activation of the transcription factor pancreas duodenum homeobox 1 (PDX1) in insulinoma cells (Eto et al. 2006, 2007), providing a link between glucose sensing and transcription of the insulin gene. PDX1 is a major regulator of insulin expression in pancreatic $\beta$-cells (Andrali et al. 2008). The regulation of PDX1 expression by Egr transcription factors was confirmed in vivo in the analysis of a transgenic mouse model expressing a dominant-negative mutant of Egr1 (Müller et al. 2012b). Accordingly, it is conceivable that pregnenolone sulfate-induced stimulation of TRPM3 activates PDX1 expression as well. In fact, Egr1 binds to the PDX1 gene under physiological conditions. Given the fact that PDX1 regulates insulin expression, pregnenolone sulfate stimulation enhances transcription of an insulin promoter/luciferase reporter gene and elevated insulin mRNA levels are detectable in pregnenolone sulfate-stimulated insulinoma cells (Mayer et al. 2011).

A direct effect of pregnenolone sulfate stimulation upon insulin secretion of insulinoma cells has been shown at glucose concentrations $>6 \mathrm{mM}$. However, insulin release from pancreatic islets cultured at low glucose concentration $(3 \mathrm{mM})$ increased only insignificantly, although pregnenolone sulfate stimulation elicited strong $\mathrm{Ca}^{2+}$ signals under these conditions (Wagner et al. 2008). This study did not distinguish between either TRPM3 and/or L-type voltage-gated $\mathrm{Ca}^{2+}$ channel activation in pregnenolone sulfate-induced insulin secretion. Recently, an additive effect of tolbutamide and pregnenolone sulfate stimulation on insulin secretion of insulinoma cells has been reported, indicating that pregnenolone sulfateinduced stimulation of TRPM3 contributes to the amount of secreted insulin. The fact that mefenamic acid reduced pregnenolone sulfate-induced insulin secretion supports the view that activation of TRPM3 channels are involved in the regulation of insulin secretion (Klose et al. 2011). TRMP3 also regulates exocytosis in other cellular systems, including interleukin secretion from vascular smooth muscle cells, hyaluronan secretion from synovial fibroblasts, and neurotransmitter release (Zheng 2009, Ciurtin et al. 2010, Naylor et al. 2010). Currently, the molecular mechanism of how TRMP3 stimulation influences the exocytotic machinery in pancreatic $\beta$-cells is unknown. Given the fact that TRPM3 regulates PDX1 expression via controlling Egr1 biosynthesis, it is possible that elevated PDX1 levels are - at least in part - responsible for this effect. This hypothesis is based on the observation that transgenic mice with an inactivated PDX1 allele secrete less insulin (Brissova et al. 2002). PDX1 also directly influences the exocytotic machinery by regulating expression of synaptotagmin 1 (Nakajima-Nagata et al. 2004), a $\mathrm{Ca}^{2+}$ sensor involved in $\mathrm{Ca}^{2+}$-dependent insulin secretion.

\section{TRPM3: an ionotropic steroid receptor of pancreatic $\beta$-cells}

The discovery that pregnenolone sulfate activates TRMP3 channels has boosted the research concerning the function of TRPM3. However, the concentration of pregnenolone sulfate required to stimulate TRPM3 channels is in the micromolar range, suggesting that pregnenolone sulfate is not a physiological agonist of TRPM3 and may have only pharmacological relevance. Typical pregnenolone sulfate concentrations measured in plasma are rather in the nanomolar and not in the micromolar range. Accordingly, it has been questioned that pregnenolone sulfate plays

Published by Bioscientifica Ltd. 
an important physiological role in insulin secretion (Colsoul et al. 2011). However, we would like to emphasize that human TRPM3 channels may have a greater sensitivity toward pregnenolone sulfate, the murine counterpart, as observed in $\mathrm{Ca}^{2+}$ measurement assays (Majeed et al. 2010).

The hypothesis that TRPM3 functions as an ionotropic steroid receptor in pancreatic $\beta$-cells responsible for modulating insulin biosynthesis and secretion implies that pregnenolone sulfate is synthesized and released in a stimulus-dependent manner. In particular, pregnenolone sulfate concentrations should be regulated by the metabolic state of the organism in order to trigger insulin secretion when insulin is required. The biosynthesis of pregnenolone sulfate starts from cholesterol that is converted to pregnenolone catalyzed by the cytochrome P450 side-chain cleavage enzyme (P450 scc). The sulfonation of pregnenolone to pregnenolone sulfate is catalyzed by hydroxysteroid sulfotransferases and involves the transfer of a sulfonate group from 3'-phosphoadenosine $5^{\prime}$-phosphosulfate to the substrate. The family of cytosolic sulfotransferases includes the enzymes SULT2A1 and SULT2B1. Differential splicing of the SULT2B1 gene generates two isoforms, SULTB2B1a and SULT2B1b (Shimizu et al. 2003), where SULT2B1a actively sulfonates pregnenolone and thus functions as a pregnenolone sulfotransferase. There are no data available that support the view that pregnenolone sulfate is specifically synthesized and released under conditions where insulin biosynthesis and secretion is required. The fact that TRPMdeficient mice did not show alterations in resting blood glucose levels (Vriens et al. 2011) indicates that TRPM3 plays no or only a marginal role in controlling $\beta$-cell functions - in contrast to the TRPM2 and TRPM5-deficient mice that showed a pre-diabetic phenotype. Nevertheless, the availability of a TRPM3-deficient transgenic mouse model, together with the recently identified pharmacological agonists and antagonists of TRPM3 (Wagner et al. 2008, Klose et al. 2011), will certainly support the functional analysis of TRPM3 channel proteins in the future.

\section{Declaration of interest}

The authors declare that there is no conflict of interest that could be perceived as prejudicing the impartiality of the review.

\section{Funding}

The research in the laboratory, concerning the role of pregnenolone sulfate stimulation in $\beta$-cells, is supported from the University of Saarland.

\section{Acknowledgements}

The authors thank Md Shahidul Islam for providing Fig. 2 and Libby Guethlein for critical reading of the manuscript.

\section{References}

Andrali SS, Sampley ML, Vanderford NL \& Özcan S 2008 Glucose regulation of insulin gene expression in pancreatic $\beta$-cells. Biochemical Journal $\mathbf{4 1 5}$ 1-10. (doi:10.1042/BJ20081029)

Arnette D, Gibson TB, Lawrence MC, January B, Khoo S, McGlynn K, Vanderbilt CA \& Cobb MH 2003 Regulation of ERK1 and ERK2 by glucose and peptide hormones in pancreatic $\beta$ cells. Journal of Biological Chemistry 278 32517-32525. (doi:10.1074/jbc.M301174200)

Benes C, Roisin MP, Van Tan H, Creuzet C, Miyazaki J-i \& Fagard R 1998 Rapid activation and nuclear translocation of mitogen-activated protein kinases in response to physiological concentration of glucose in the MIN6 pancreatic $\beta$ cell line. Journal of Biological Chemistry 273 15507-15513. (doi:10.1074/jbc.273.25.15507)

Benes C, Poitout V, Marie J-C, Martin-Perez J, Roisin M-P \& Fagard R 1999 Mode of regulation of the extracellular signal-regulated kinases in the pancreatic $\beta$-cell line MIN6 and their implication in the regulation of insulin gene transcription. Biochemical Journal 340 219-225. (doi:10.1042/0264-6021:3400219)

Bernal-Mizrachi E, Wice B, Inoue H \& Permutt MA 2000 Activation of serum response factor in the depolarization induction of Egr-1 transcription in pancreatic islet $\beta$-cells. Journal of Biological Chemistry 275 25681-25689. (doi:10.1074/jbc.M003424200)

Bernal-Mizrachi E, Wen W, Srinivasan S, Klenk A, Cohen D \& Permutt MA 2001 Activation of Elk-1, an Ets transcription factor, by glucose and EGF treatment of insulinoma cells. American Journal of Physiology. Endocrinology and Metabolism 281 E1286-E1299.

Brissova M, Shiota M, Nicholson WE, Gannon M, Knobel SM, Piston DW, Wright CVE \& Powers AC 2002 Reduction in pancreatic transcription factor PDX-1 impairs glucose-stimulated insulin secretion. Journal of Biological Chemistry 277 11225-11232. (doi:10.1074/jbc.M111272200)

Brixel LR, Monteilh-Zoller MK, Ingenbrandt CS, Fleig A, Penner R, Enklaar T, Zabel BU \& Prawitt D 2010 TRPM5 regulates glucose-stimulated insulin secretion. Pflügers Archive: European Journal of Physiology 460 69-76. (doi:10.1007/s00424-010-0835-z)

Cao DS, Zhong L, Hsieh TH, Abooj M, Bishnoi M, Hughes L \& Premkumar LS 2012 Expression of transient receptor potential anlyrin 1 (TRPA1) and its role in insulin release from rat pancreatic $\beta$ cells. PLoS ONE 7 e38005. (doi:10.1371/journal.pone.0038005)

Chen L \& Sokabe M 2005 Presynaptic modulation of synaptic transmission by pregnenolone sulfate as studied by opical recordings. Journal of Neurophysiology 94 4131-4144. (doi:10.1152/jn.00755.2004)

Chen L, Cai W, Chen L, Zhou R, Furuya K \& Sokabe M 2010 Modulatory metaplasticity induced by pregnenolone sulfate in the rat hippocampus: a leftward shift in LTP/LTD-frequency curve. Hippocampus 20 499-512. (doi:10.1002/hipo.20718)

Ciurtin C, Majeed Y, Naylor J, Sukumar P, English AA, Emery P \& Beech DJ 2010 TRPM3 channel stimulated by pregnenolone sulphate in synovial fibroblasts and negatively coupled to hyaluronan. BMC Musculoskeletal Disorders 11 111. (doi:10.1186/1471-2474-11-111)

Colsoul B, Schraenen A, Lemaire K, Quintens R, Van Lommel L, Segal A, Owsianik G, Talavera K, Voets T, Margolskee RF et al. 2010 Loss of high-frequency glucose-induced $\mathrm{Ca}^{2+}$ oscillations in pancreatic islets correlates with impaired glucose tolerance in Trpm5-/- mice. PNAS 107 5208-5213. (doi:10.1073/pnas.0913107107)

Colsoul B, Vennekens R \& Nilius B 2011 Transient receptor potential cation channels in pancreatic $\beta$ cells. Review of Physiological and Biochemical Pharmacology 161 87-110. (doi:10.1007/112_2011_2)

Corbit KC, Trakul N, Eves EM, Diaz B, Marshall M \& Rosner MR 2003 Activation of Raf-1 signaling by protein kinase $\mathrm{C}$ through a mechanism http://jme.endocrinology-journals.org DOI: 10.1530/JME-12-0237
C 2013 Society for Endocrinology Printed in Great Britain 
involving Raf kinase inhibitory protein. Journal of Biological Chemistry 278 13061-13068. (doi:10.1074/jbc.M210015200)

Duan L \& Cobb MH 2010 Calcineurin increases glucose activation of ERK1/2 by reversing negative feedback. PNAS 107 22314-22319. (doi:10.1073/pnas.1016630108)

Eto K, Kaur V \& Thomas MK 2006 Regulation of insulin gene transcription by the immediate early response gene Egr-1. Endocrinology 147 2923-2935. (doi:10.1210/en.2005-1336)

Eto K, Kaur V \& Thomas MK 2007 Regulation of pancreatic duodenum homeobox-1 expression by early growth response-1. Journal of Biological Chemistry 282 5973-5983. (doi:10.1074/jbc.M607288200)

Frödin M, Sekine N, Roche E, Filloux C, Prentki M, Wollheim CB \& Van Obberghen EV 1995 Glucose, other secretagogues, and nerve growth factor stimulate mitogen-activated protein kinase in the insulin-secreting $\beta$ cell line, INS-1. Journal of Biological Chemistry 270 7882-7889. (doi:10.1074/jbc.270.14.7882)

Frühwald J, Camacho Londono J, Dembla S, Mannebach S, Lis A, Drews A, Wissenbach U, Oberwinkler J \& Philipp SE 2012 Alternative splicing of a protein domain indispensable for function of transient receptor potential melastatin 3 (TRPM3) ion channels. Journal of Biological Chemistry 287 36663-36672. (doi:10.1074/jbc.M112.396663)

Glauser DA \& Schlegel W 2007 Sequential actions of ERK1/2 on the AP-1 transcription factor allow temporal integration of metabolic signals in pancreatic $\beta$ cells. FASEB Journal 21 3240-3249. (doi:10.1096/fj.067798 com)

Glauser DA, Brun T, Gauthier BR \& Schlegel W 2006 Transcriptional response of pancreatic $\beta$ cells to metabolic stimulation: large scale identification of immediate-early and secondary response genes. BMC Molecular Biology 8 54. (doi:10.1186/1471-2199-8-54)

Grimm C, Kraft R, Sauerbruch S, Schulz G \& Harteneck C 2003 Molecular and functional characterization of the melastatin-related cation channel TRPM3. Journal of Biological Chemistry 278 21493-21501. (doi:10.1074/jbc.M300945200)

Grimm C, Kraft R, Schultz G \& Harteneck C 2005 Activation of the melastatin-related cation channel TRPM3 by D-erythro-sphingosine. Molecular Pharmacology 67 798-805. (doi:10.1124/mol.104.006734)

Halokovska B, Grycova L, Jirku M, Sulc M, Bumba L \& Teisinger J 2012 Calmodulin and S100A1 protein interact with $\mathrm{N}$ terminus of TRPM3 channel. Journal of Biological Chemistry 287 16645-16655. (doi:10.1074/ jbc.M112.350686)

Hara Y, Wakamori M, Ishii M, Maeno E, Nishida M, Yoshida T, Yamada H, Shimizu S, Mori E, Kudoh J et al. 2002 LTRPC2 $\mathrm{Ca}^{2+}$-permeable channel activated by changes in redox status confer susceptibility to cell death. Molecular Cell 9 163-173. (doi:10.1016/S1097-2765(01)00438-5)

Hige T, Fujiyoshi Y \& Takahashi T 2006 Neurosteroid pregnenolone sulfate enhances glutamatergic synaptic transmission by facilitating presynaptic calcium currents at the calyx of Held of immature rats. European Journal of Neuroscience 24 1955-1966. (doi:10.1111/j.14609568.2006.05080.x)

Horak M, Vlcek K, Petrovic M, Chodounska H \& Vyklicky L Jr 2004 Molecular mechanism of pregnenolone sulfate action at NR1/NR2B receptors. Journal of Neuroscience 24 10318-10325. (doi:10.1523/ JNEUROSCI.2099-04.2004)

Islam MS 2011 TRP channels of islets. In: transient receptor potential channels. Advances in Experimental Medicine and Biology 704 811-830. (doi:10.1007/978-94-007-0265-3_42)

Jang MK, Mierke DF, Russek SJ \& Farb DH 2004 A steroid modulatory domain on NR2B controls $N$-methyl-D-aspartate receptor proton sensitivity. PNAS 101 8198-8203. (doi:10.1073/pnas.0401838101)

Josefsen K, Sorensen LR, Buschard K \& Birkenbach M 1999 Glucose induces early growth response gene (Egr-1) expression in pancreatic $\beta$ cells. Diabetologia 42 195-203. (doi:10.1007/s001250051139)

Klose C, Straub I, Riehle M, Ranta F, Krautwurst D, Ullrich S, Mayerhof W \& Harteneck C 2011 Fenamates as TRP channel blocker: mefenamic acid selectively blocks TRMP3. British Journal of Pharmacology 162 1757-1769. (doi:10.1111/j.1476-5381.2010.01186.x)
Kobayashi T, Washiyama K \& Ikeda K 2009 Pregnenolone sulfate potentiates the inwardly rectifying K channel Kir2.3. PLOS ONE 4 e6311. (doi:10.1371/journal.pone.0006311)

Kolch W, Heidecker G, Kochs G, Hummel R, Vahidi H, Mischak H, Finkenzeller G, Marmé D \& Rapp UR 1993 Protein kinase C $\alpha$ activates RAF-1 by direct phosphorylation. Nature 364 249-252. (doi:10.1038/ 364249a0)

Kostakis E, Jang MK, Russek SJ, Gibbs TT \& Farb DH 2011 A steroid modulatory domain in NR2A collaborates with NR1 exon-5 to control NMDAR moduation by pregnenolone sulfate and protons. Journal of Neurochemistry 119 486-496. (doi:10.1111/j.1471-4159.2011. 07442.x)

Lee N, Chen J, Sun L, Wu S, Gray KR, Rich A, Huang M, Lin J-H, Feder JN, Janovitz EB et al. 2003 Expression and characterization of human transient receptor potential melastatin 3 (hTRPM3). Journal of Biological Chemistry 278 20890-20897. (doi:10.1074/jbc.M211232200)

Majeed Y, Agarwal AK, Naylor J, Seymour VAL, Jiang S, Muraki K, Fishwick CWG \& Beech DJ 2010 Cis-isomerism and other chemical requirements of steroid agonists and partial agonists acting at TRPM3 channels. British Journal of Pharmacology 161 430-441. (doi:10.1111/ j.1476-5381.2010.00892.x)

Majeed Y, Bahnasi Y, Seymour VAL, Wilson LA, Milligan CJ, Agarwal AK, Sukumar P, Naylor J \& Beech DJ 2011 Rapid and contrasting effects of rosiglitazone on transient receptor potential TRPM3 and TRPM5 channels. Molecular Pharmacology 79 1023-1030. (doi:10.1124/mol. 110.069922)

Majeed Y, Tumova S, Green BL, Seymour VAL, Woods DM, Agarwal AK, Naylor J, Jiang S, Picton HM, Porter KE et al. 2012 Pregnenolone sulphate-independent inhibition of TRM3 channels by progesterone. Cell Calcium 51 1-11. (doi:10.1016/j.ceca.2011.09.005)

Mayer SI \& Thiel G 2009 Calcium influx into MIN6 insulinoma cells induces expression of Egr-1 involving extracellular signal-regulated protein kinase and the transcription factors Elk-1 and CREB. European Journal of Cell Biology 88 19-33. (doi:10.1016/j.ejcb.2008.07.002)

Mayer SI, Müller I, Mannebach S, Endo T \& Thiel G 2011 Signal transduction of pregnenolone sulfate in insulinoma cells. Activation of Egr-1 expression involving TRPM3, voltage-gated calcium channels, ERK, and ternary complex factors. Journal of Biological Chemistry $\mathbf{2 8 6}$ 10084-10096. (doi:10.1074/jbc.M110.202697)

Müller I, Endo T \& Thiel G 2010 Regulation of AP-1 activity in glucose-stimulated insulinoma cells. Journal of Cellular Biochemistry 110 1481-1494. (doi:10.1002/jcb.22715)

Müller I, Rössler OG \& Thiel G 2011 Pregnenolone sulfate activates basic region leucine zipper transcription factors in insulinoma cells: role of voltage-gated $\mathrm{Ca}^{2+}$ channels and transient receptor potential melastatin 3 channels. Molecular Pharmacology 80 1179-1189. (doi:10.1124/ mol.111.074781)

Müller I, Lipp P \& Thiel G $2012 a \mathrm{Ca}^{2+}$ signaling and gene transcription in glucose-stimulated insulinoma cells. Cell Calcium 52 137-151. (doi:10.1016/j.ceca.2012.05.003)

Müller I, Rössler OG, Wittig C, Menger MD \& Thiel G 2012b Critical role of Egr transcription factors in regulating insulin biosynthesis, blood glucose homeostasis and islet size. Endocrinology 153 3040-3053. (doi:10.1210/en.2012-1064)

Nakajima-Nagata N, Sugai M, Sakurai T, Miyazaki J-i, Tabata Y \& Shimizu A 2004 Pdx-1 enables insulin secretion by regulating synaptotagmin 1 gene expression. Biochemical and Biophysical Research Communications 318 631-635. (doi:10.1016/j.bbrc.2004.04.071)

Naylor J, Li J, Milligan CJ, Zeng F, Sukumar P, Hou B, Sedo A, Yuldasheva N Majeed Y, Beri D et al. 2010 Pregnenolone sulphate- and cholesterolregulated channels coupled to vascular smooth muscle secretion and contraction. Circulation Research 106 1507-1515. (doi:10.1161/CIRCRESAHA.110.219329)

Oberwinkler J, Lis A, Giehl KM, Flockerzi V \& Philipp SE 2005 Alternative splicing switches the divalent cation selectivity of TRPM3 channels.

Published by Bioscientifica Ltd. 
Journal of Biological Chemistry 280 22899-22906. (doi:10.1074/jbc. M503092200)

Shimizu C, Fulda H, Yanai H \& Strott CA 2003 Conservation of the hydroxysteroid sulfotransferase SULT2B1 gene structure in the mouse: pre- and postnatal expression, kinetic analysis of isoforms, and comparison with prototypical SULT2A1. Endocrinology 144 1186-1193. (doi:10.1210/en.2002-221011)

Straub I, Mohr F, Konrad M, Philipp SE, Oberwinkler J \& Schaefer M 2013 Citrus fruit and fabacea secondary metabolites potently and selectively block TRPM3. British Journal of Pharmacology 168 1835-1850. (doi:10.1111/bph.12076)

Thiel G, Mayer SI, Müller I, Stefano L \& Rössler OG 2010 Egr-1 - a Ca ${ }^{2+}$. regulated transcription factor. Cell Calcium 47 397-403. (doi:10.1016/ j.ceca.2010.02.005)

Trus M, Corkey RF, Nesher R, Richard AM, Deeney JT, Corkey BE \& Atlas D 2007 The L-type voltage-gated $\mathrm{Ca}^{2+}$ channel is the $\mathrm{Ca}^{2+}$ sensor protein of stimulus-secretion coupling in pancreatic $\beta$ cells. Biochemistry $\mathbf{4 6}$ 14461-14467. (doi:10.1021/bi7016816)

Uchida K, Dezaki K, Damdindorj B, Inada H, Shiuchi T, Mori T, Yada T, Minokoshi Y \& Tominaga M 2011 Lack of TRPM2 impaired insulin secretion and glucose metabolisms in mice. Diabetes 60 119-126. (doi:10.2337/db10-0276)
Vriens J, Owsianik G, Hofmann T, Philipp SE, Stab J, Chen X, Benoit M, Xue F, Janssens A, Kerselaers S et al. 2011 TRPM3 is a nociceptor channel involved in the detection of noxious heat. Neuron 70 482-494. (doi:10.1016/j.neuron.2011.02.051)

Wagner TFJ, Loch S, Lambert S, Straub I, Mannebach S, Mathar I, Düfer M, Lis A, Flockerzi V, Philipp SE et al. 2008 Transient receptor potential M3 channels are ionotropic steroid receptors in pancreatic $\beta$ cells. Nature Cell Biology 10 1421-1430. (doi:10.1038/ncb1801)

Wang M 2011 Neurosteroids and GABA-A receptor function. Frontiers in Neuroendocrine Science 2 44. (doi:10.1111/bph.12076)

Wang Q, Cai K, Pang S, Wang T, Qi D, Zhu Q, Ni Z \& Le Y 2008 Mechanisms of glucose-induced expression of pancreatic-derived factor in pancreatic $\beta$-cells. Endocrinology 149 672-680. (doi:10.1210/en. 2007-0106)

Yang M, Chisholm JW, Soelaiman S \& Shryock JC 2010 Sulfonylureas uncouple glucose-dependence for GPR40-mediated enhancement of insulin secretion from INS-1E cells. Molecular and Cellular Endocrinology 315 308-313. (doi:10.1016/j.mce.2009.09.033)

Zheng P 2009 Neuroactive steroid regulation of neurotransmitter release in the CNS: action, mechanism and possible significance. Progress in Neurobiology 89 134-152. (doi:10.1016/j.pneurobio.2009. 07.001)

Received in final form 27 February 2013

Accepted 19 March 2013

Accepted Preprint published online 19 March 2013
(C) 2013 Society for Endocrinology Printed in Great Britain
Published by Bioscientifica Ltd. 